\title{
沿岸海域の懸濁態粒子の粒径分布の現地測定とデトリタス分布
}

\author{
熟 見 栄 -*・鋤 崎 俊 二**
}

\section{1. ま.えがき}

沿岸海域の懸濁態粒子は, 粘土やシルトの無機態粒子, 有機性の非生物態粒子（デトリタス）および動植物プラ ンクトン類等からなる.それらの粒子は個々の粒子の物 性に応じて, 沿岸海域の中で違った挙動を示すと思われ る.ここでは, 沿岸海域の水中で直接に測定した懸濁態 粒子の粒径分布とデトリタスとの関係について検討す る.

\section{2. 懸濁態粒子の粒径分布とデトリタス}

\section{1 眊濁態粒子の粒径分布の測定方法}

海域における懸濁態粒子の粒径分布は, コールター・ カウンターによって長らく測定されてきている。この計 測器の問題点は, 海水試料を採水した後に実験室で分析 する方法が取られることである。これらの操作の間で粒 子によっては崩壊し, 水中に存在した粒子の粒径分布と は違った結果になる（Johnson ら，1994）。

最近, 懸濁態粒子の体積濃度の粒径分布を現地の（in situ）水中で測定できるレーザー光散乱を使った計測器 が開発された（Agrawal・Pottsmith，2000)。ここでは 1.25〜250 $\mu \mathrm{m}$ の範囲を測定できる SEQUOIA 社の LISST-100を使用した. 本計測器は上記の粒径範囲を対 数的に 32 分割して測定できるが, $4.36 \mu \mathrm{m}$ 以下に種々の 雑音が入るために，5.11 $\mu \mathrm{m}$ 以上を図示した。最小サン プル間隔は 0.385 秒間である.水深は, 深度計の分解能に よって 8〜 $9 \mathrm{~cm}$ おきに測定される. 校正は標準粒子（例 えば，JSR 社製）を使うが，沿岸海域では形状も物性も 違う粒子が多く存在するため, 堆積物について実験室で の測定例が報告されてきている(Traykovski ら，1999).

図一1 は，培養された鞭毛藻 (Pavlova lutheri) と伊勢 湾 (四日市港沖) で赤潮を形成した鞭毛藻 (Prorocentrum sigmoides）を 2000 年 10 月 17 日に現地測定した例（熟 見・鋤崎，2001）を示す。前者は球状で粒径は約 $6 \mu \mathrm{m}$ で あるが,この計測器では $6.03 \mu \mathrm{m}$ にピークを持ってい た. 後者は棈円状で等価粒径が $26.3 \mu \mathrm{m}$ であったが,

\footnotetext{
* 正会員 工博 (独) 産業技術総合研究所

** 俶日本海洋生物研究所
}

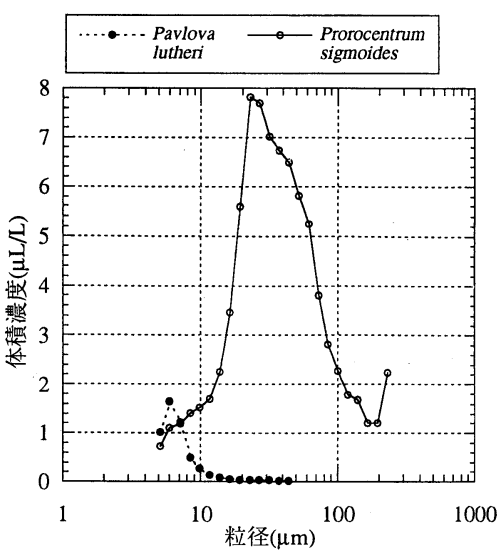

図一1 培養された鞭毛藻 (Pavlova lutheri) と伊勢湾での鞭 毛藻 (Prorocentrum sigmoides)

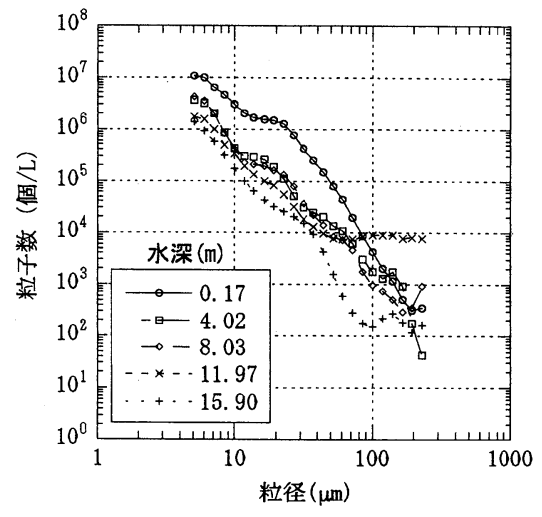

図一2 伊勢湾での水深方向の粒子数の粒径分布

$22.7 \mu \mathrm{m}$ から $26.7 \mu \mathrm{m}$ にピークを持っていた. 表層で採 水した試料を顕微鏡で計数した結果, 189 万個/Lであっ た. LISST-100 で測定された水深 $0.17 \mathrm{~m}$ の上記の二つ の粒径の粒子数を合計すると，205万個/Lになった（図 -2). 以上のように, 培養した単一種や赤潮のように単 一種が優占しやすい場合には，生物態粒子でも測定でき ることが判った。

図一 2 は, 上記の伊勢湾における水深方向の粒子数の 粒径分布である. LISST-100によって測定された体積濃 
度から等価粒径 $(d)$ を使って粒子数に換算した. 表層で 赤潮の鞭毛藻が上乗せされたような傾向が現れ, 底層に 向かって大きな粒子が相対的に増加していた。一般的な 海域では，大きな粒子から順次に累積した粒子数 $(N)$ を 使った $N=a d^{-m}$ によって検討される。 $m$ が 3 以上の場 合は小さい粒子が多く, $m$ が 3 以下の場合は大きな粒子 が多いことを示す (McCave，1984)。この場合は，水深 $4 \mathrm{~m}$ から底層までmは 3 以下であり大きな粒子が多かっ た.

\section{2 デトリタス濃度の推定方法と粒径分布}

図一 3 は, 多摩川の表層河川水 $\mathrm{A}, \mathrm{B}$ (図一5 の T1) と 四日市港から流出した海底上約 $1 \mathrm{~m}$ の底層水の懸濁態 粒子の粒径分布である.多摩川 A は 2000 年 6 月 15 日 に, 多摩川 B は 2001 年 2 月 28 日に, 四日市港は 1999 年 8 月 12 日に測定した. $80 \mu \mathrm{m}$ 辺りにピークを持つ比較的 に単純な粒径分布であった。この粒径のピークは種々の 場に普遍的に顕著に現れ, 生物態粒子とは考えにくく, また, この大きさの無機態粒子がその沈降速度から常に 浮遊していることも考えにくい.このため, 懸濁態粒子 の構成からデトリタスと考えた。

デトリタス量の見積もり方法は現在でも確立されてい ないため,ここでは次の方法で見積った(小川ら, 1994 ； 環境庁，1997)。植物プランクトンは，炭素/クロロフィ ル (C/Chl. a) 比を一定 (36) と仮定し, Chl. a 濃度にそ の比を乗じて植物プランクトン炭素量とした。動物プラ クトンは, 種類ごとの個体数と体積を顕微鏡により測定 し, 平均体積と個体数から既存の換算ファクターを用い て炭素量を推定した。微小鞭毛虫 (HMF) についても同 様である。バクテリアは, DAPI 染色によって計数された 全菌数に炭素含量ファクター $(20 \mathrm{fgC} / \mathrm{cell})$ を乗じてバク テリア炭素量とした。デトリタス量は, 懸濁態有機炭素 (POC) から植物プランクトン, 動物プランクトン, $\mathrm{HMF}$ およびバクテリアの炭素量を差し引いて算出した。

表一 1 は, 多摩川の表層河川水 $\mathrm{A}, \mathrm{B}$ と四日市港加ら流 出した海底上約 $1 \mathrm{~m}$ の底層水の $\mathrm{POC}$ の組成とその比率 である.ただし，POCと SS(懸濁物量)の比は， $24.9 \%$, $27.9 \%, 4.9 \%$ であった.多摩川の A ではデトリタスの比 率は $94.0 \%, \mathrm{~B}$ では $79.8 \%$ であった. A ではほとんど生 物態粒子が無くデトリタスであるが，Bではデトリタス の比率が少なく植物プランクトンが $15.4 \%$ 含まれてい た。

図-3 の粒径分布で比較すると, A では $80 \mu \mathrm{m}$ 辺りに ピークを持つ形であったが, Bでは $20 \mu \mathrm{m}$ 辺りにピーク が重なっていた，Bでは試料を異なる孔径のふるいで分 画したが, $63 \sim 125 \mu \mathrm{m}$ で $\mathrm{C} / \mathrm{N}$ は 1.6 と小さく, $80 \mu \mathrm{m}$ 辺 りの粒子は凝集性有機態粒子 (aggregate) が大部分と考 えられた。四日市港ではデトリタスの比率は $77.5 \%$ であ

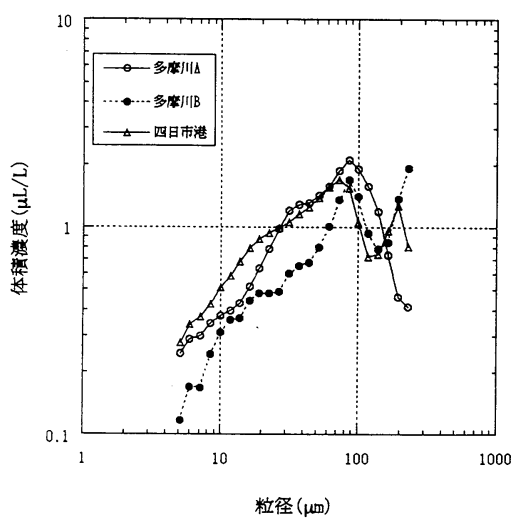

図一3 多摩川の表層河川水と四日市港から流出した海底上 約 $1 \mathrm{~m}$ の底層水の懸濁態粒子の粒径分布

表一1 多摩川の表層河川水と四日市港から流出した海底 上約 $1 \mathrm{~m}$ の底層水の $\mathrm{POC}$ の組成と比率

\begin{tabular}{l|r|r|r|r|r|r}
\hline & POC & $\begin{array}{l}\text { 植物プラ } \\
\text { ンクトン }\end{array}$ & $\begin{array}{c}\text { 動物プラ } \\
\text { ンクトン }\end{array}$ & HMF & バクテリア & デトリタス \\
\hline 多摩川A & 2494 & 25.2 & 49.1 & 2.7 & 72.8 & 2344.1 \\
& 100 & 1.0 & 2.0 & 0.1 & 2.9 & 94.0 \\
\hline 多摩川B & 1450 & 223.2 & 19.5 & 2.7 & 47.0 & 1157.6 \\
& 100 & 15.4 & 1.3 & 0.2 & 3.2 & 79.8 \\
\hline 四日市港 & 618 & 50.4 & 23.9 & 1.1 & 63.7 & 478.8 \\
& 100 & 8.2 & 3.9 & 0.2 & 10.3 & 77.5 \\
\hline
\end{tabular}

上段：濃度 $(\mu \mathrm{gC} / \mathrm{L})$, 下段：比率 $(\%)$

り，同じ傾向であった。このように，流入する河川水中 の懸濁態粒子および沿岸海域で沈降した海底上の懸濁態 粒子ともに，ほぼ同じような粒径分布を持ち，POCの中 でデトリタスの比率が非常に高いことが得られた。

\section{3. 汽水域と沿岸海域における懸濁態粒子の粒 径分布}

\section{1 多摩川における㲘濁態粒子の粒径分布}

河川から流入した懸濁態粒子が海水中で電荷的に凝集 する現象は古くから知られているが，室内実験による実 証や概念図になることが多い。ここでは, 現地で測定し た懸濁態粒子の粒径分布の傾向から検討する.

図一 4 は，汽水域の多摩川と沿岸海域の東京湾の測定 点を示す.多摩川では, 河川水である丸子橋 $\mathrm{T} 1$ から河口 の T13, 東京湾では, 河川流量の大きい荒川の影響を把 握するために $\mathrm{A} 1$ から $\mathrm{A} 6$, 東京港内水の影響を把握する ために B1 から B5 のライン観測を行った。

図一5 は, 1999 年 7 月 28 日に扔ける多摩川の干潮時の 塩分断面分布である. 多摩川大橋上流から河床近くに海 水が認められ，典型的な緩混合型になっていた。しかし， 多摩川大橋下流から六郷橋にある塩分 10 の等濃度線に 


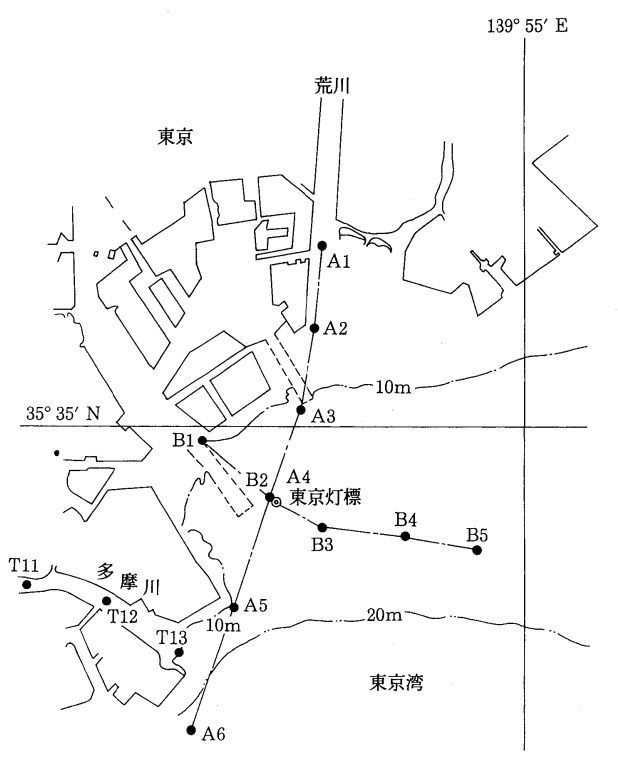

図-4 多摩川と東京湾の測定点

見られるように，この区間の河床近傍は海水の滞留域に なっていた。図中の斜線部は, 塩分勾配がある程度に変 化し，次に述べる懸濁態粒子の大きな粒径の体積濃度が 大きく増加する部分を示す。

図一 6 は, T7 における水温・塩分と懸濁態粒子の体積 濃度の鉛直分布を示す。体積濃度は代表的な粒径だけを 示している. 表層から水深 $2 \mathrm{~m}$ までは, 河川水の時と同 じょうに各粒径ともに体積濃度は鉛直方向に一様であっ た. 水深 $2 \mathrm{~m}$ から $44.0 \mu \mathrm{m}$ と $85.2 \mu \mathrm{m}$ の体積濃度は増 加し, 水深約 $3 \mathrm{~m}$ で最大になって, それょり下層では 徐々に減少していた。塩分は, 水深 $2 \mathrm{~m}$ から $3 \mathrm{~m}$ で 3.56 から 5.62 亿徐々に増加し, 水深 $3.5 \mathrm{~m}$ では 11.77 と急 激に増加し躍層になっていた。躍層上のある厚さに大き な粒子が集積滞留し, 躍層下から徐々に減少している過 程は他の地点でも見られた。 大きな粒径の体積濃度が増 加し減少していく層を, 図一5 の中に斜線部で示してあ る.

河川から流入した懸濁態粒子は海水中で電荷的に凝集 していると思われるが，懸濁態粒子の体積濃度の粒径分 布からは aggregationによってより大きな粒子に成長し ていることが推定された。

\section{2 東京湾における懸濁態粒子の粒径分布}

汽水域から沿岸海域へ懸濁態粒子が流入していく過程 を把握するために, 荒川の A ライン (図一4)について年 間の調査を行っている. 図一7は, 2000 年 8 月 18 日の濁 度 (C) と 9 月 14 日における懸濁物量 (SS) の断面分布で ある。濁度は濁度計 (アレック社製 PT-1) によって, 懸 濁物量は重量法によって測定した。 8 月では荒川河口か

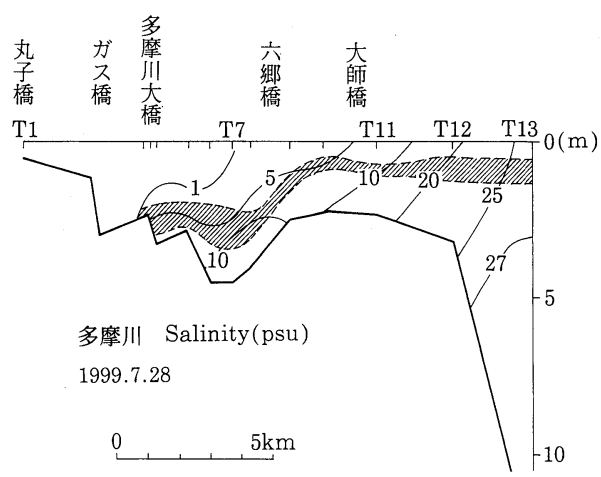

図一5 多摩川の干潮時の塩分断面分布

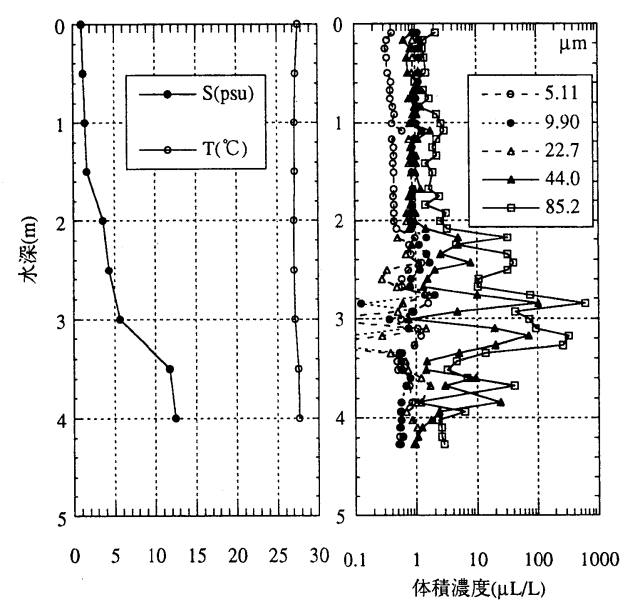

图一6 T7 に抢ける水温・塩分と懸濁態粒子の体積濃度の鉛 直分布

ら濁度の高い汽水域の水が東京湾に流入し，一部は表層 を輸送され，一部は底層に沿って輸送されていた．中層 に濁度の低い (3 mg/L 以下) 海水が侵入していた。この パターンは，他の河川の流出過程の場合にもよく見られ る. 東京港内水の流出過程を把握するために行った 1999 年 9 月 28 日の B ラインでもほほ同じ傾向であった。

図一8 は, A4 における 8 月 18 日の水温・塩分と懸濁態 粒子の体積濃度の鉛直分布を示す。体積濃度は代表的な 粒径だけを示している。塩分は河川水の影響で表層から 徐々に増加し約 $2 \mathrm{~m}$ で躍層になっており, 約 $6 \mathrm{~m}$ と約 $13 \mathrm{~m}$ にも躍層があった. $0 \mathrm{~m}$ から $0.76 \mathrm{~m}$ の表層では, 各 粒径の体積濃度はほほ一様であった。約 $1.5 \mathrm{~m} て ゙$, 各粒 径ともに体積濃度は增加しており, 大きな粒径 $(44.0 \mu \mathrm{m}$ と $85.2 \mu \mathrm{m}$ ) の体積濃度は特に大きく増加していた. 約 $6 \mathrm{~m}$ より下層では, 小さな粒径の体積濃度は急激に減少 していた. 大きな粒径の体積濃度は, 約 $6 \mathrm{~m}$, 約 $11 \mathrm{~m}$ お よび約 $13 \mathrm{~m}$ で増加しているが，ほぼ躍層周辺で増加し ていた．躍層上で増加し，躍層より下層で徐々に減少し 


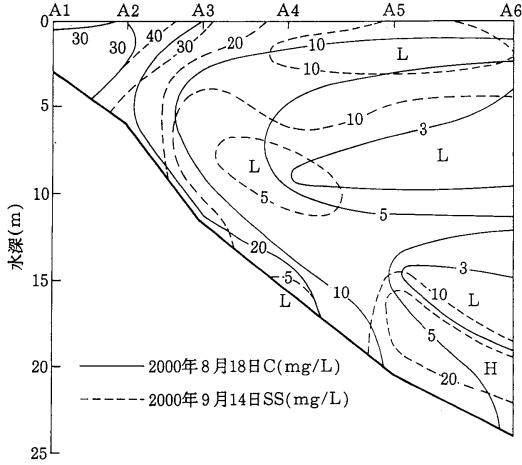

図一7 荒川の A ラインの濁度 (C) と懸濁物量 (SS) の断面 分布

ていく過程は汽水域での過程と同じであった。

図一9 は，A ラインにおける 9 月 14 日の海底上約 $1 \mathrm{~m}$ における懸濁態粒子の粒径分布の空間的変化である，前 日までの降雨によって荒川が増水し, A1 と A2 の表層は 褐色の濁水であった. A1, A2 の表層の䀣濁物量は, それ ぞれ $47.3 \mathrm{mg} / \mathrm{L}, 56.0 \mathrm{mg} / \mathrm{L}$ であった. $\mathrm{A} 1$ は $85.2 \mu \mathrm{m}$ に ピークを持つ単純な粒径分布であり, A2 から A 5 にかけ て急激に $85.2 \mu \mathrm{m}$ の体積濃度は減少していた. 相対的に A3 からは十数 $\mu \mathrm{m}$ のピークが顕著になる傾向を示して いた. 大きな粒子ほど底層を輸送される時に海底に沈降 していく結果と考えられた.A6で再び体積濃度が増加 しているが, 多摩川河口の T13 からの輸送と思われた。

図一10 は，荒川のA ラインの海底上約 $1 \mathrm{~m}$ における 懸濁物量 (SS), POC 中のデトリタスの比率 $(r)$ およ び POC, 植物プランクトン, 動物プランクトン, バクテ リアとデトリタスの炭素濃度である. T13 は A ライン上 でないが, 位置関係から A5 と A6の間に示してある.デ トリタスの比率は, A1 の底層で $82.8 \%, \mathrm{~A} 1$ と A2 の表 層で $86.0 \% ， 76.3 \%$ あった。しかし，A2 の底層では $32.7 \%$ と低かった. A3 の中層水の值 (35.0〜 37.3\%) に 近く, 植物プランクトンの炭素濃度が高いことから, A3 近傍の中層水が $\mathrm{A} 2$ に補償的に流入してきたと考えられ た.A5では $72.4 \%$ と高いが, それまでに底層を輸送され てきた増水時の影響が残っていたためと思われた（図 一7).これらの測定点を除いた A3, A4, A6 および T13 の 4 点の平均値は $58.1 \%$ あっあた. 伊勢湾では, 赤潮が あった点を除いた 5 点の平均值は $60.0 \%$ あった（鷲 見・鋤崎，2001）。東京湾と瀬戸内海の底層において濁度 の平均沈降速度が同じ $0.02 \mathrm{~cm} / \mathrm{s}$ であったこと（熟見・ 田中，1999）に対応するように, 懸濁態粒子の粒径分布 とデトリタスの比率は両海域でほほ同じであった。
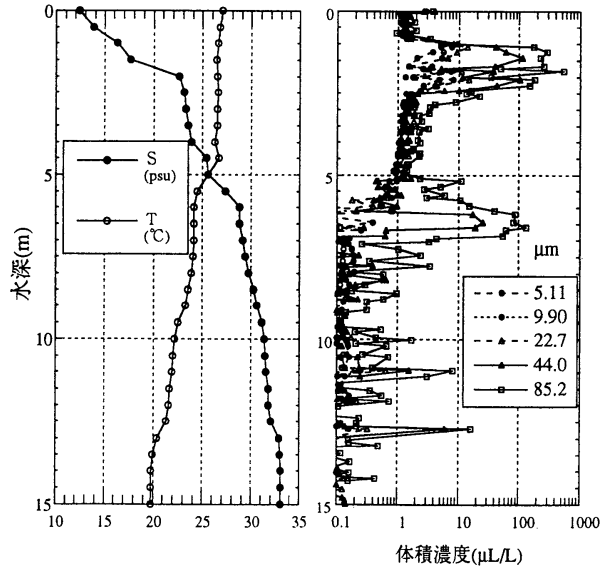

图一8 A4 における水温・塩分と懸濁態粒子の体積濃度の鉛 直分布

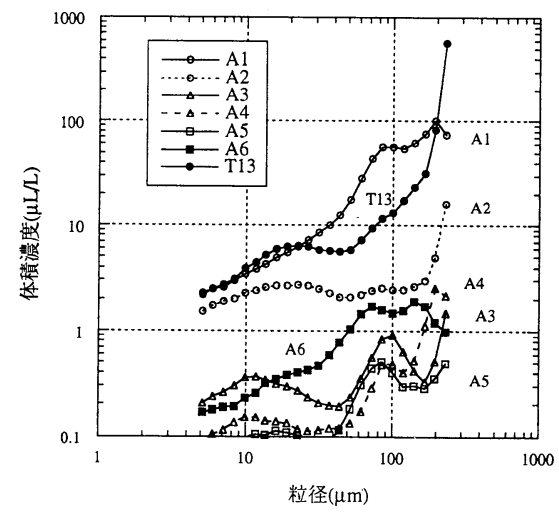

図一9 荒川の A ラインの海底上約 $1 \mathrm{~m}$ における䀣濁態粒子 の粒径分布の空間的変化

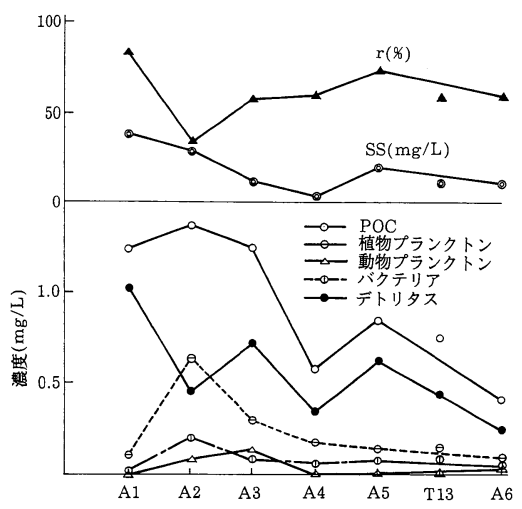

図一10 荒川の A ラインの海底上約 $1 \mathrm{~m}$ における懸濁物量 (SS), POC 中のデトリタスの比率 $(r)$ および POC, 植物プランクトン, 動物プランクトン, バクテリア とデトリタスの炭素濃度 


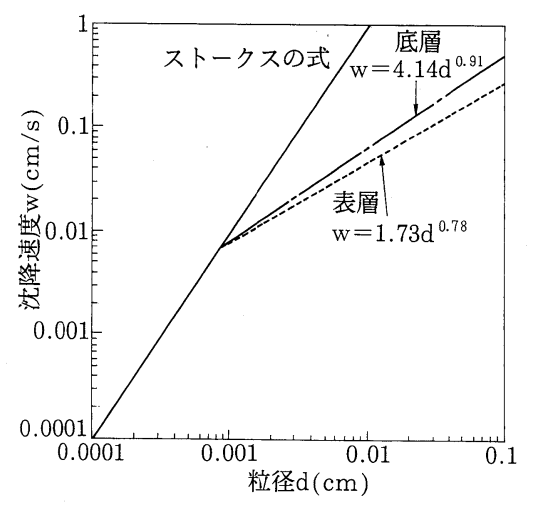

図-11 凝集性有機態粒子と無機態粒子の沈降速度

\section{4. あとがき}

河川水中の懸濁態粒子は, $80 \mu \mathrm{m}$ 辺りにピークを持つ 粒径分布で，ほとんどがデトリタスと考えられた。汽水 域から沿岸海域に流入する過程において，躍層上に集積 滞留し, $80 \mu \mathrm{m}$ 辺りの体積濃度は急激に増加していた。 海底近くの底層でも，この粒径のピークが卓越した粒径 分布になっていた。このように季節や場所（河川，汽水 域，沿岸底層）にかかわらず存在するものとして，デト リタスである凝集性有機態粒子が考えられた。この粒子 は古くから知られているが，その形成機構は未解明な点 が多い.

図一11 は, 過去に得られた凝集性有機態粒子と無機態 粒子の沈降速度 $(w)$ と粒径 $(d)$ との関係である.た だし, 沈降速度と粒径の単位は $\mathrm{cm} / \mathrm{s}$ と $\mathrm{cm}$ である. 表層 の式は Gibbs（1985）によって，底層の式は谷本・星加 （1994）によって現地で測定された結果である。無機態粒 子（比重；2.65）の沈降速度は, ストークスの式（ $w=$ $\left.8976 d^{2}\right)$ から計算したものである。約 $10 \mu \mathrm{m}$ 以上で，同 じ粒径の沈降速度は，表層，底層，ストークス式の順に 大きくなっている。ここで興味深いのは，表層と底層の
二つの式が, 約 $10 \mu \mathrm{m}$ でストークスの式に交差している ことである.物理的なモデルを考えると, 約 $10 \mu \mathrm{m}$ 以下 の無機態粒子は，表層や底層の式に従って aggregation し粒径が大きくなっていると考えれば，表層にあった小 さい粒子が底層では少なくなり，底層で大きな粒子が卓 越してくる現象を説明することができる。

謝辞：培養された鞭毛藻 (Pavlova lutheri) の提供で, 愛知県水産試験場鈴木輝明漁場改善研究室長にご協力を 頂きました。ここに記してお礼申し上げます。

\section{参 考 文 献}

小川浩史・嶋村茂・亭島博彦・加藤憲二・石川公敏 (1994)：内 湾における微小食物連鎖と有機物循環, 1994 年度日本海洋学 会春季大会講演要旨集, p. 363.

環境庁企画調整局研究技術課編（1997）：沿岸生態系における内 部生産物質の循環過程と環境影響評価技術に関する研究, 平 成 9 年度環境保全研究成果集 (II), 46- I-1-46- I- 68.

鷲見栄一・鋤崎俊二 (2001)：伊勢湾の懸濁態粒子の粒径分布と 組成に関する考察, 2001 年度日本海洋学会春季大会講演要旨 集, p. 302 .

熟見栄一・田中祐志 (1999)：沿岸域の底層における懸濁態粒子 の物理的挙動, 海岸工学論文集, 第 46 巻, pp. 991-995.

谷本照巳・星加 章 (1994)：大阪湾と江田内湾における眯濁粒 子の沈降速度, 海の研究, Vol. 3, No. 1, pp. 13-20.

Agrawal, Y. C. and H. C. Pottsmith (2000): Instruments for particle size and settling velocity observations in sediment transport, Marine Geology, Vol. 168, pp. 89-114.

Gibbs, R. J. (1985): Estuarine flocs : their size, settling velocity and density, J. Geophy. Res., Vol. 90, pp. 3249-3251.

Johnson, B. D., K. Kranck and D. K. Muschenheim (1994): Physicochemical factors in particle aggregation, in the Biology of Particles in Aquatic Systems, edited by R. S. Wotton, Lewis Publishers, pp. 75-96.

McCave, I. N. (1984): Size spectra and aggregation of suspended particle in the deep ocean, Deep Sea Research, Vol. 31, No. 4, pp. 329-352.

Traykovski, P., R. Latter and J. D. Irish (1999): A laboratory evaluation of the laser in situ scattering and transmissometery instrument using natural sediments, Marine Geology, Vol. 159, pp. 355-367. 